IOSR Journal of Pharmacy

ISSN: 2250-3013, www.iosrphr.org

Volume 2 Issue 5 ||| Sep-Oct. 2012 \||| PP.35-37

\title{
Present status of trout fisheries in jammu and kashmir
}

\author{
Noor-ul Hassan ${ }^{1}$, and Devendra N. Pandey ${ }^{2}$ \\ ${ }^{1}$ Research Scholar Department of Zoology, Govt. S.K.N. (PG) College Mauganj, Rewa \\ ${ }^{2}$ Asst. Prof. Department of Zoology, Govt. S.K.N. (PG) College Mauganj, Rewa (M.P.)
}

\begin{abstract}
The research paper provided detailed information about the introduction of Trout in Kashmir. In Kashmir Valley Trout was introduced in 1899 by F.J. Mitchell who bought a consignment of eyed-eggs of Brown Trout from England (Mitchell, 1918). This whole consignment however, perished in the way due to heat. In 1900 another consignment of eyed-eggs of same species was produced from Howeitonin in Scotland. The swim-up fry from these eggs were successfully reared up to the adulthood and the first spawning or eggtaking of the Brown-Trout (Salmo trutta fario), was done in December 1905 at Harwan near Srinagar (Kashmir). In the 1905-1906, Mitchell succeeded in establishing a regular Trout Hatchery at Harwan Srinagar Kashmir, having a capacity of 100,000 green eggs. Since then brown trout has established itself throughout Kashmir and parts of Jammu notably in Badarwah and Poonch providing fly and spoon fishing year after year to thousands of anglers visiting the state.It was from Kashmir that brown trout was spread to other sections of the Himalayas. In 1912, Mitchell Succeeded in hatching and rearing rainbow trout eggs from a consignment presented to him by the Bristol Water Works England. Today J\&K Fisheries Department ha achieved remarkable success and at present 32 trout rearing units are functioning in various Districts of $J \& K$ state. The Fisheries Department collects huge revenue from sale outlets of trout fishes located at various parts of the state.
\end{abstract}

Keywords-Trout Fish, Jammu and Kashmir

\section{INTRODUCTION}

The environment, topography, climate etc. of $\mathrm{J} \& \mathrm{~K}$ is well suitable for breeding, rearing, production and marketing of trout fishes. The snow-fed and glacier-fed streams, mountains, lakes and spring of the state boost the healthy environment of trout fishes. Trout is a cold water fish and well flourishes in water temperature ranges from $5^{\circ} \mathrm{C}$ to $15^{\circ} \mathrm{C}$.

In J\&K state two species of trout brown trout (Salmo trutta fario), and rainbow trout (Oncorhynchus mykiss) are popular.

The river of Kashmir valleys are rich in fish fauna, many of which are commercially important. The rainbow trout is reared at various trout rearing units of $\mathrm{J} \& \mathrm{~K}$ state for sale and this variety of trout has so demand in the state that Department of Fisheries fails to cater trout to all the customers. Besides usual customers trout fish is being supplied to hotels and restaurants as it adds to their daily sale having a good respond.

The physico-chemical parameters of water of J\&K state particularly of Kashmir Valley are beneficial and productive for trout fishes. As a proof, the survival rate of trout eggs in Kashmir is about $10 \%$ higher than the Western average of $46 \%$. When the British introduced the brown trout and rainbow trout to Kashmir, at the same time they introduced the system of angler's reserving beats on their favourite rivers. Tourists are much attracted to fish angling in Kashmir.

\section{TROUT SEED PRODUCTION AND HATCHERY MANAGEMENT}

In $\mathrm{J} \& \mathrm{~K}$ state five seed producing hatcheries come breeding projects are located at Laribal (Srinagar), Kokernag (Anantnag), Shokababa (Baramulla), Mammar (Srinagar), Phalni (Rajouri). The breeding season of trout fish starts in November. The breeding operations are carried out in controlled conditions. For this, Department of Fisheries has parent stock as healthy brooders. By the method of striping eggs of trout fish are obtained artificially after segregating male and female brooders. From the eggs fingerling are raised at selected hatcheries as mentioned above. Then these fingerlings are supplied to big and small trout rearing units of state. Theses hatcheries function on scientific and technological grounds with assistance from European countries.

The trout seed production has increased to 2.12 million eggs per annum (annual report of J\&K Fisheries Department 2010-11). Besides the department have two National Fish seeds farm, one at Kathua (Jammu) and another at Manasbal Kashmir. The Department of Fisheries has sent trout seed to neighboring states / countries like Himachal Pradesh, Skimm and Bhutan. 


\section{TROUT REARING UNITS CUM SALE CENTRES}

Under trout fisheries the department has at present 32 trout rearing units functioning at every nook and corner of the state. More units in newly created Districts, like Beja (Badarwah), Aliyalpora (Shopian), Chanser (Kulgam), Krichi (Udhampur), Surasyar, Basantwoder (Budam), Guzerbal (Bandipora), Dawar (Gurez) are under construction. Pertinently in the post one decade not only the new trout rearing units like Uri, Kalantra (Baramulla), Kutlari (Kupwara), Bani (Kathua), Nobra (Leh), Panzeth and Nambal (Anantnag) were constructed but also the existing trout units were upgraded by way of increasing their rearing capacity and space. The hatching capacity of Kokernag Trout Farm was enhanced. The various units like Achhabal (Anantnag), Khag (Budgam), Jogigund (Anantnag) were rehabilitated and made functional rearing units.

Trout feed:-The trout has a varied diet. These are highly carnivorous, predators, eating any smaller fish form nearly the time they are born. Insects make up a large portion of their diet. Although it is rainbow trout reared at various trout rearing units of the state. Department of Fisheries feeds these trout fishes artificially. The Department has already got two feed mills at Kokernag and Harwan. These suffice only the stocks available in the department, whereas for privatization, one more feed manufacturing plant is required. The estimated cost of the additional feed is 5.50 crore (Annual Report Department of Fisheries, 2010-11).

Unlike other varieties of fish, trout must have a special feed containing special ingredients and requisite percentage of proteins, vitamins, carbohydrate, etc. for which a specially designed feed mill is required, and that is not fabricated any where in the Indian Sub continent. It is likely to be imported from outside that is either from Holland, Scotland, Denmark, U.K. and U.S.A.

Training potential:-The concept of importing necessary training to the in-service field staff all the department, In-service fisheries Training Centre (IFTC) was established in the late fifties, at Achhabal in the District Anantnag and later it was shifted to Kokernag within the premises of Trout Fish Farming Project. Trout Fish Farming Project Kokernag was established at a pace-setter and testing ground for rainbow trout (Oncorhynchus mykiss), but with the efficient management technique and skilled staff, it has given a thrust to boost trot production and experts. This training institute was established in 1957 and it has so for produced 1209 in service training staff of the Department of Fisheries in the state (Leaflet of IFTC published for publicity 2008).

Trout production:-The trout fish production is very high in J\&K state, with low mortality rate due to the favorable climatic conditions of state. Trout is a cold water fish so climatic conditions of the state particularly of Kashmir Division is feasible for breeding, stocking, feeding, rearing, production and marketing of trout fishes. The trout fish production has increased to 155 tonnes during 2010-11, which was 90 tonnes during 2002-03 (Annual Report of J\&K Fisheries Department 2010-11 and 2002-03).

It is evidence that fish production is gradually increased year after year in the state. The present production is not enough and sufficient to meet the demands of the local people as trout fish is highly valued fish in the state due to its nutritive value, less spines and easy to cook. Trout fish has also very high demand outside the state but the production is not enough to supply it outside the state.

Trout in private sector:-The Government of $J \& K$ has identified various major thrust areas of overall development of trout fisheries in the state. Necessary infrastructure shall be raised by the authorities. In this direction the Department of Fisheries is planning to introduction trout culture in private sector for which an additional feed mill is being installed during this financial year. The National Fisheries Development Board had already sanctioned Rs. 3.10 crores under this scheme. (Source Department of Fisheries J\&K).

Under the Prime Minister's Economic Package (PMEP) for construction of private fish ponds in the state, the beneficiary is provided $100 \%$ subsidy for the constriction and maintenance of the fish pond. Numerous unemployed educated youth have been incorporated in this scheme and the progress.

Trout marketing:-During the last three years the trout sale has almost doubled and the trout sale during the last financial year was to the tune of Rs. 116 Lacs against rs. 92 Lacs in 2009-10 (Annual Reports of Department of Fisheries 2009-10 and 2010-11).

For marketing, the department has a special sales outlet a Srinagar, besides sales centers at all 32 trout rearing units, as all these units are trout rearing cum sales centers. The Government of J\&K approved and fixed Rs. 200/- per 2 Kilograms of trout fish for domestic consumption. Once customer is allowed to buy only two kilograms of trout fish at a time. If a customer intends to additional kilograms of trout fish, he has to pay Rs. 400/- per kilograms as commercial rate. Due to high demand and response of trout fish in market which is increasing day by day, the Government has fixed and approved Rs. 400/- per kilogram as commercial rate of trout fish for hotels and restaurants.

Now a days people have become health conscious so they prefer trout fish as it is rich in proteins, vitamin A, B, B1, C2, D, Omega 3 polyunsaturated fatty acids and low in Sodium and forms the basis for healthy low fat diet. Trout is regarded by some gourmets (food experts) as one of the most delicious types of fish in the world. The trout is put to sale when it reaches to the growth of 250 grams a this weight is preferred as table size of trout fish to cook it into delicious recipes. 


\section{CONCLUSION}

The foregoing gives, in brief, the present states of trout fisheries in J\&K state. The J\&K state, particularly Kashmir Valley, the Paradise on Earth, is abundant in natural, pollution-free water resources, which can be developed by adopting better management hatcheries which function of scientific conditions of water, climate, temperature etc. in the state. These marvelous features contribute to the high survival and low mortality rate of trout fries, fingerlings and yearlings. Out of five species of trout fishes, only rainbow and brown varieties were adapted to Kashmiri Rivers. Kashmir began cultivating trout in large numbers only in the mid 1980's, and the Fisheries Department J\&K started marketing more than a decade later. In Kashmir which is rich in natural water resources, fisheries sector has a vast business potential. The state government is providing all facilities including financial assistance and technical support for this purpose.

There is considerable scope to develop trout culture on scientific lines. These include maintenance of healthy brood stock, control of diseases and evolving nutritive artificial diet for intensive feeding of trout fish. Such measure if taken, can give better results and performance of trout farms and make available disease resistance fingerlings and yearling and undertake mass-scale transplantation of rivers, streams, springs and lakes of J\&K state by trout fishes.

The state government had launched Prime Minister's Economic Packages (PMEP) and sufficient funds have been provided to Fisheries Department J\&K, to setup, to fish ponds and fish rearing units at district and sub-district level. 454 such units have been setup across the state. In a year 100 educated youth could be earn their livelihood by means of trout farming (Director Fisheries Department J\&K).

The state government has already taken steps to renovate old trout farms and to establish new trout farms at Achhabal (Anantnag), Khag (Budgam), Jogigund (Anantnag). Eight new trout rearing units are under construction.

Fishermen and anglers also enjoyed trout fishing in the state at a large scale. In order to develop tourism in the state, it is necessary to promote sport fishery so that anglers could be attracted to the state. This will add to the source of indirect income to the people of J\&K state. Considerable efforts will have to made in this direction.

Lastly enforcement of fish laws should be carried out to prevent illegal trout fishing. This also calls for building proper infrastructure in the state by providing proper training to Fisheries Department officials in enforcing various conservation measures.

\section{ACKNOWLEDGEMENTS}

The author expresses his deep sense of gratitude and sincere obligations to hi research guide/supervisor Dr. Devendra Nath Pandey, Professor of Zoology, Govt. S.K.N. (PG) College Mauganj Rewa (MP) for his valuable suggestions, guidance, encouragement and moral support. The author is grateful to various officials of Department of Fisheries J\&K for providing unto-date and accurate information on trout fishes. The author also owes thanks to officials working at various trout rearing units and hatcheries of J\&K State.

\section{REFERENCES}

[1]. Annual Reports published by the Department of Fisheries J\&K State.

[2]. Jhingran, V.G. and Sehgal, K.L. (1978) - Cold water Fisheries of India, Inland Fisheries Society of India.

[3]. Mitchell, F.J., (1918) - How trout were introduced in Kashmir. Bombay Nat. Hist. Soc. 26(1):176-79 and 295-99.

[4]. Richardson - A report on abnormalities of larvae of rainbow trout from Kokernag Trout Farm, Kashmir (J\&K). Oriental Science, 6(1):9-22. 